\title{
PARENTAL INTERVENTIONS TOWARDS LEARNERS' MENTAL HEALTH IN TIMES OF THE COVID 19 PANDEMIC
}

\author{
Tarhata S. Guiamalon ${ }^{1 \star}$, Sanjiavela S. David ${ }^{2}$ and Sofia U. Camsa ${ }^{3}$ \\ ${ }^{1}$ Assoc.Prof. Dr., Cotabato State University, Philippines, \\ tarhataguiamalon@yahoo.com \\ ${ }^{2}$ Teacher 1, Lipao Elementary School, Maguinadano I Division, BARMM \\ ${ }^{3}$ Teacher III, Datu Nakan Memorial Elementary School, Bagumbayan, \\ Sultan Kudarat Division, Region XI \\ ${ }^{*}$ Corresponding Author
}

\begin{abstract}
Parental interventions regarding mental health needs and counseling play an important role in their children's mental health as it prevents their children's mental health with symptoms such as anxiety, depression, school closings, and a reduction in social connection. This study used the descriptive correlation method. This study mainly looked at the relationship between parental interventions and the mental health of the students of sixth-grade parents from the southern district of Datu Paglas. The respondents were 72 class parents. According to the data collected, the results showed that there is no significant relationship. between parental interventions and student mental health. The results also showed that parents' individual perceptions of the situation, and in particular the difficulty for them to cope with the many pressures caused by the pandemic, were linked to a significant degree with the parental and mental stress of children's problems and effects on the psychological and emotional problems of children through the mediating role of parental interventions. Parents took care of their children's learning and had time for themselves, their partner, their children, and the activities they had been doing before the pandemic.
\end{abstract}

Keywords: Parents Intervention, Mental Health, Covid 19 Pandemic

\section{INTRODUCTION}

With the onset of global development, the mental health problem associated with the COVID 19 pandemic has rapidly increased the burden o public health. (Torales et al., 2020). It is profoundly affecting life around the globe. According to Wang et. al, (2020), COVID 19 has identified a heightened prevalence of moderateto-serve self-reported depressive and anxious symptomology among the public. Mental health is one of the causes of COVID-19 Pandemic to learners. While many parents have had to work from home, they took care of and act as tutors of their children. Parents are facing challenges in their ability to assume responsibility as teachers for their children. They are now taking on a more support-oriented role by supporting their children as they take on assignments and home projects (Benjamin, 1993; Ceka \& Murati, 2016; Emerson et al., 2012). Cognizant of these, this study was conducted to determine the parents' intervention to their children's mental health in a time of the pandemic.

\subsection{Related Studies}

Many research results on the mental health implications of COVID-19 have identified a higher prevalence of moderate to severe self-reported depressive and anxiety symptoms in public (Wang et al., 2020), reflecting the widespread effects of uncertainty and health-related anxiety. However, further research that investigates 
beyond the population level is necessary to understand the individualized changes in lives and routines as a result of COVID-19 and its associated psychological effects. Also, Torales et al. (2020) confirmed that mental health issues associated with COVID 19 pandemic have rapidly increased the burden on public health.

The World Health Organization (WHO) declared last January 30, 2020, a public health emergency of International Concern after the first group of people infected by COVID-19 were diagnosed in China (WHO, 2020). Cancellation of all sporting events and closure of schools and universities across the country (government, 2020); With the schools, all educational support services for children of all ages were closed, and teachers from elementary school were giving online lectures. Everyone was forbidden from leaving the house, with the exception of health or work reasons that could not be postponed and documented or other urgent matters. Smart work has been encouraged, but with most activities ceased, many people have lost their jobs or suffered a sharp drop in income. Families' living conditions changed suddenly and profoundly. In the home environment, parents play an educational role to their children than before. Children only have their parents around to do homework and encourage positive development and new learning experiences for toddlers and preschoolers (Wang et al., 2020) While quarantine means that time with loved ones has increased, it also poses a problem. A huge burden for parents as they take on an educational role while trying to lead their own lives and carry on with their daily work commitments. This situation has significantly increased the risk of stress and negative emotions in children's parents, with a possible cascade effect on children's well-being (Sprang \& Silman, 2013). Therefore, mobility restrictions and social isolation related to quarantine, despite its beneficial effect in reducing the number of newly infected cases, are major concerns for the mental wellbeing of families. In this context, the country's health situation is fragile, which requires attention. Hospitals are overcrowded and the number of deaths, infected and convalescent in hospitals continues to increase (government, 2020). It is becoming increasingly common to meet at least one person who tested positive for COVID-19 or was hospitalized and has unfortunately experienced the loss of a person to COVID-19, which can cause fear and concern in parents and children. also for families who have no health problems.

Research about students' mental health underlines the need for educators in considering the effect of mental health on students. This is imperative how mental illness may hinder students' success. (Breslau, Lane, Sampson, \& Kessler, 2008; Cranford, Eisenberg, \& Serras, 2009; Elion, Wang, Slaney, \& French, 2012).Klaus Grawe $(2004,2007)$ developed a vision of mental functioning from conceptualizations formed in conventional contemporary psychology, but with a certain "driver" that may not be entirely "mainstream" ie "the goals that a person" while her psychology forms "life, ultimately they serve to satisfy various basic needs". (Grawe, 2007, p.169) Grawe defined the most important basic psychological needs as the core of his consistency theory, through which our behavior is driven to adapt these needs to healthy or Pathological ways to meet. Motivational schemes (forms and means we develop to meet a need) and are generally focusdriven (from cortical processes) or avoidance-driven (from limbic processes). My intention is not to use the consistency theory in this article to describe in detail, but simply to look at what the These basic needs are consistent with Grawe.

There are four basic needs: the need for attachment; the need for control/guidance; the need for pleasure/avoidance of pain; and the need for personal improvement. Of these needs, attachment and control develop first and are therefore the strongest drivers of behavior, with personal improvement or self-esteem being the ultimate needs that must develop in an individual. During the COVID-19 outbreak, national quarantine policies may affect parents' mental health. However, few studies have looked at parental mental health during the COVID-19 pandemic. The mental health of students poses a major public health challenge (Stallmann, 2008; Storrie et al., 2010). A systematic review found that half of the students who reported symptoms of mental distress had also experienced these symptoms prior to their studies. while the remaining half-developed them during their studies. Other studies from the USA, Canada, and the UK confirm that university students are more likely to have mental health problems compared to the general population of the same age group (Adalf et al., 2001; Bewick et al., 2010)

Keyes et al, opined that psychological distress has been linked to lower academic self-efficacy and poor academic progress. A longitudinal study from the US found that mental health problems predict a delay in academic achievement (GPA), suggesting a direction of influence (Eisenberg et al., 2009). In addition, both factors can be linked to factors that operate at different levels, from individual factors to interpersonal problems and institutional characteristics. Studies have reported that emotional problems negatively impacted academic progress and dropout rates in higher education (Robbins et al., 2004; Storrie et al., 2010). There are more than 2.2 billion children in the world who make up approximately $28 \%$ of the world's population. People between the ages of 10 and 19 make up $16 \%$ of the world's population (UNICEF, 2019). COVID-19 has affected the lives of people around the world, including children and adolescents, in 
unprecedented ways. The COVID-19 infection involves isolation and social distancing strategies to protect against the risk of infection (Shen et al., 2020), which is why several countries began implementing containment measures or regional and national closings in January 2020 to have. As background, one of the most important measures taken while in detention has been the closure of schools, educational institutions, and areas of activity, unstoppable circumstances beyond the normal experience causing stress, fear, and a feeling of helplessness. We have different theories about the exact number and type of basic psychological needs, some suggesting a particular hierarchy of psychological needs, while others postulating a combination of many different needs of equal value.

\subsection{Statement of the Study}

The study aims to determine parents' interventions towards learners Mental Health in times of pandemic. Specifically, the extent of the parent's intervention in terms of Psychological needs assessment, Guidance, and counseling and the extent of the learner's mental health such as Anxiety Symptoms, Depression, School Closures, and Restricted Social Connection. Further, the study finds out if parents' interventions have an association with pupils' mental health.

\subsection{Significance of the Study}

In many ways, whether on a tiny scale or in a wide range scale the findings of this research were benefit the following individuals in their own respective fields:

The DepEd Authorities. The Department of Education main goal is to be able to produce productive citizens of the community. DepEd also aims to make every graduate be locally and globally competitive in many aspects most especially in academics. This study would give them ideas to facilitate the programs of every school to be more efficient and effective for the growth of every individual.

The School Administrator. After evaluating all factors that contribute to the parents' interventions to students' mental health, the school administrator can do more effective programs to support the lacking and needs of the students.

The Teachers. This research will also benefit the teachers of Datu Paglas South District of the Division of Maguindanao-I for having more strategies in education regarding those alternative interventions to students.

The Students. This research focuses on the students who really need intervention during this time of the pandemic. Some children and young people may be feeling more isolated, anxious, bored, and uncertain. They may feel fear, and grief, over the impact of the virus on their families. But with this Parents' intervention will leave a huge impact on them.

\section{METHODOLOGY}

This study primarily examined the relationship between parental interventions and the mental health of students of sixth-grade parents from the southern district of Datu Paglas. The respondents were 72 PTA class presidents. In order to collect the necessary data, a constructed survey tool was used, validated by the education supervisory authorities of the Datu Paglas district and a pilot study was carried out.

\section{RESULTS}

\subsection{Results on Parents Involvement}

\subsubsection{Parental Involvement on Psychological Needs}

Table 1 shows the extent of parental interference with students' mental health in relation to mental needs. The overall mean of 3.93, interpreted as "highly evident", indicates that parents are devoting their time and effort to their children in order for them to better understand the real situation and to introduce them to the necessary tasks in times of the pandemic. It also shows that parents are encouraging their children to keep learning during the COVID19 pandemic. As Secretary of the Philippine Department of Education (DepEd) Leonor Briones asserted: "Education must continue even in times of crisis, be it an accident, a disaster, an emergency, a quarantine or even a war" (Ministry of Education, 2020). According to Undersecretary and Spokesperson for the Department of Education, Annalyn Sevilla, the department has finalized a learning continuity plan through the concerned units to ensure that "training continues in emergencies. 
Table 1. Parental Interventions in Learners mental health in terms of Psychological Needs

\begin{tabular}{|c|c|c|}
\hline Statements & Mean & Interpretation \\
\hline $\begin{array}{l}\text { 1. Give time to talk about situations } \\
\text { on the new normal education. }\end{array}$ & 3.97 & Highly Evident \\
\hline $\begin{array}{l}\text { 2.Encourages the child to continue } \\
\text { education through modular learning. }\end{array}$ & 3.97 & Highly Evident \\
\hline $\begin{array}{l}\text { 3. Helps the child in answering his/her } \\
\text { modules. }\end{array}$ & 3.81 & Highly Evident \\
\hline $\begin{array}{l}\text { 4. Ask the child of his/her difficulty in } \\
\text { answering modules. }\end{array}$ & 3.90 & Highly Evident \\
\hline 5.Provides learning materials if necessary. & 3.94 & Highly Evident \\
\hline 6. Gives free time for playing. & 3.81 & Highly Evident \\
\hline $\begin{array}{l}\text { 7.Makes the time for modules for fun } \\
\text { and easier to accomplish. }\end{array}$ & 3.94 & Highly Evident \\
\hline $\begin{array}{l}\text { 8. Explains to the child the real problem. } \\
\text { on education to be safe from pandemic. }\end{array}$ & 4.00 & Highly Evident \\
\hline $\begin{array}{l}\text { 9.Introduces to the child more about life } \\
\text { for the awareness of this pandemic. }\end{array}$ & 4.00 & Highly Evident \\
\hline $\begin{array}{l}\text { 10.Understands their mood swings } \\
\text { as result of boredom. }\end{array}$ & 3.92 & Highly Evident \\
\hline Mean Average & 3.93 & Highly Evident \\
\hline
\end{tabular}

Legend

$\begin{array}{ll}3.46-4.00 & \text { Highly Evident } \\ 2.46-3.45 & \text { Evident } \\ 1.36-2.45 & \text { Less Evident } \\ 1.00-1.37 & \text { Least Evident }\end{array}$

\subsubsection{Parental Involvement on Guidance and Counselling}

Table 2 shows the extent of parental "interventions" in learner's mental health on guidance and counseling. The overall mean of 3.98, interpreted as "very obvious", means parents are setting clear rules and directing students to emphasize modular learning education to be safe from COVID19. The result also means that parenting interventions for student mental health in terms of guidance and counseling show how they can help the child develop life skills and appropriate behavior. Similarly, DepEd establishes a distance learning approach that uses three methods: (1) providing printed modules to students, (2) access to DepEd Commons, an online educational platform developed by DepEd to support alternative modes of learning. Learning and (3)) providing lessons or self-study modules on radio and television. However, the specific guidelines for implementing distance learning are still under review (Magsambol, 2020). As the Department's Secretary, Leonor Br. Iones stated, "We have presented a variety of options online with a number of options. Not the only answer, there is a lot of debate in the Philippines about how useful or whether it is really a good one Possibility is to teach students. So we have online, we have televisions, we have radio. When all else 
fails, learning modules are printed which can be delivered to various collection points or parents or distributed to students by village officials," he said.

Table 2. Parental Interventions in Learners mental health in terms of Guidance and Counselling

Indicators Mean Interpretation

1.Set clear rules when out at home.

2.Maintain regular sleep for children.

3.Educate children about how to be Safe from COVID19.

4.Emphasize other options about having fun.

5.Let them learn the safety protocols to avoid COVID19.

\section{Practice health precautionary measure at home.}

7.Encourage them to be interested in modular distance learning.

8. Guide them to their modular learning.

9. Focus on the weakness of the child.

10. Helping the children develop life skills and appropriate behavior.
4.00
Highly Evident
3.89
Highly Evident
3.96
Highly Evident

$\begin{array}{ll}3.97 & \text { Highly Evident } \\ 4.00 & \text { Highly Evident }\end{array}$

4.00

Highly Evident

4.00

Highly Evident

3.96

Highly Evident

4.00

Highly Evident

3.97

Highly Evident

Mean Average $\quad 3.98 \quad$ Highly Evident

\subsection{Results on Learner's Mental Health-Related}

\subsubsection{Mental Health-Related to Anxiety Symptoms}

Table 3 shows the data from learner's mental health-related to anxiety symptoms. The overall mean of 1.24 , interpreted as "highly evident", means that the learners experiencing anxiety symptoms during the enhanced community quarantine (ECQ). Accordingly, despite worries and helplessness because of the pandemic, learners have been encouraged by their parents to focus on education and are defenseless to a virus. Parents Have Proper Guidance and Support to Get Their Children interested. Depression and anxiety, in turn, often affect memory and focus, making it difficult to acquire and manage new knowledge. They often increase the perception of hopelessness and inadequacy and keep many people feeling anxious and depressed in a vicious circle (Rice et al., 2006; Stallmann, 2008). According to the Department of Health the new realities of working from home, temporary unemployment, home-schooling of children, and lack of physical contact with other family members, friends, and colleagues take getting used to. Adapting to such lifestyle changes and managing the fear of contracting the virus and concern for those around us who are particularly at risk is a challenge for everyone. especially difficult for people with mental health problems. According to Brooks, S., Webster, R., Smith, L., Woodland, L., Wessely, S., Greenberg, N... et al., (2020). Quarantine is often an uncomfortable experience for those who suffer from it. Separation from loved ones, 
loss of freedom, uncertainty about disease status, and boredom can sometimes have dramatic effects

Table 3. Learners' Mental health Related to Anxiety Symptoms

\begin{tabular}{llll}
\hline \multicolumn{1}{c}{ Indicators } & Mean & Interpretation \\
\hline $\begin{array}{l}\text { 1. Worries about education at home. } \\
\text { 2.Have difficulty in adjusting to modular distance }\end{array}$ & 1.10 & Least Evident \\
learning & 1.04 & Least Evident \\
3 Fear losing control of thinking of COVID19. & 1.93 & Less Evident \\
$\begin{array}{l}\text { 4.Nervous about getting the virus within his/her area. } \\
\text { 5.Have fear of losing relatives. }\end{array}$ & 1.06 & Least Evident \\
$\begin{array}{l}\text { 6. Have fear of the worst happening In education. } \\
\text { 7.Have fear of increasing in cases of COVID19 }\end{array}$ & 1.04 & Least Evident \\
$\begin{array}{l}\text { 8. He/She thinks that Pandemic Never end and maybe } \\
\text { education will stop }\end{array}$ & 1.10 & Least Evident \\
$\begin{array}{l}\text { 9.Overthinking on how to survive to this pandemic. } \\
\text { 10.Increasing his/her sense of being helpless when }\end{array}$ & 1.04 & Least Evident \\
the virus will hit him/her. & 2.03 & Less Evident \\
\hline$\quad$ Mean Average & 1.24 & Least Evident \\
\hline
\end{tabular}

Legend
$3.46-4.00$
Highly Evident
$2.46-3.45$
Evident
$1.36-2.45$
Less Evident
$1.00-1.37$
Least Evident

\subsubsection{Mental Health-Related to Depression}

Table 4 indicates the Learner's mental health-related to depression. The overall mean of 1.44 which is interpreted as "Less evident" denotes that the learners were depressed in the hardest time of the pandemic. Hence, the parents need to closely guide their children during the quarantine period. They have more time to encourage their children to continue their education in times of pandemics. According to Dr. Reinecke (www.www.queenstechhs.org), Very often, depressed children and teens, like adults, have negative thoughts about themselves, their lives, their relationships, and their future, He further emphasized that they feel hopeless, helpless, and discouraged. Listen for these thoughts. Help them to clarify what's on their mind and how they're feeling." As stated by DepEd Undersecretary and Spokesperson Annalyn Sevilla the parents should take advantage of the opportunity to teach their children problem-solving, resilience, and preparedness for times of emergencies, among others. "Children can teach older people while they are at home too by helping to be more familiarized with the use of technology,"

Table 4. Learners' Mental Health Related to Depression

\begin{tabular}{|c|c|c|}
\hline Indicators & Mean & Interpretation \\
\hline 1. Th & & \\
\hline happen again & 1.99 & Less Evident \\
\hline 2. Feels that enable to see Friends and classmates. & 1.28 & Least Eviden \\
\hline
\end{tabular}


3. Feels that they never enjoy with his/her friends.

4. Never has fun.

5. Feels that never go outing with friends and classmates in this time of pandemic.

6 . Feels that he/she stays at home forever.

7. Feeling irritable Staying at home for months

8. Thinks that her friends never stay at home starting the new normal.

9.Bursting out of complaints about headache or stomach ache because of boredom. 10.Has a Feelings of worthlessness or guilt.
1.18 Least Evident
1.36 Least Evident

1.33 Least Evident

1.11 Least Evident

1.04 Least Evident

1.14 Least Evident

1.93 Less Evident

2.00 Less Evident

\begin{tabular}{lll}
\hline Mean Average & 1.44 & Less Evident \\
\hline Legend
\end{tabular}
$3.46-4.00$
Highly Evident
$2.46-3.45$
Evident
$1.36-2.45$
Less Evident
$1.00-1.37$
Least Evident

\subsubsection{Mental Health-Related to Schools Closures}

Table 5 indicates the Learner's mental health-related to Schools closures. The overall mean of 1.52 which is interpreted as "less evident" shows that the perceptions of the learners on school closure were not permanent. Time will come after this health crisis; normal schooling will resume. But still, education must be continued even if there is a Pandemic. In addition, different learning modalities are applied in many ways such as online and learning from home through modules. Parents are properly oriented and motivated to help their children to continue learning this time of the pandemic. De Vera, (2020b) felt that the "spirit of Bayanihan," needs to be emphasized, a unique Filipino value of communal unity, De Vera also stated that there's a need to find ways to deal with the pandemic during these years challenging times and ensuring that "learning must continue," "we learn as one, we are ready". According to the DepEd Secretary Leonor Briones in her speech during the High-Level Social Development Goals Action Event on Education, she presented at the United Nations in New York City on June 28, 2017. She also stressed that "Whatever happens in the country; regardless of the challenges we face, education must continue. Education cannot wait; Our learners can hardly wait. We are continuing the process so to give hope and continuity, and to help normalize activities in the country," the Secretary said in part of the speech on the High-Level Social Development Goals Action Event in Education that she presented at the United Nations in New York City on June 28, 2017.

Table 5. Learners Mental Health on School Closures

\begin{tabular}{lll}
\hline \multicolumn{1}{c}{ Indicators } & Mean & Interpretation \\
\hline $\begin{array}{l}\text { 1.Thinks of modular learning is the only way } \\
\text { of educating them. }\end{array}$ & 1.97 & Less Evident \\
$\begin{array}{l}\text { 2. Feels that never have class in school. } \\
\text { 3.He/She thinks that education has done only at home }\end{array}$ & 1.11 & Least Evident \\
4.Thinks of school will never open for face-to-face I & 1.94 & Least Evident \\
\end{tabular}

learning. 

5. Always asks for opening of school.
1.00 Least Evident
6.Frequently asking what will be the mode of learning.
1.93 Less Evident
7.Always reminding parents about his/her school
Supplies
$1.97 \quad$ Less Evident
8.thinks that the teacher will not be at school anymore. $1.83 \quad$ Less Evident
9. Has many queries about the continuation
of school.
$1.14 \quad$ Least Evident
10.Is in doubt about the Distance learning.
1.03 Least Evident
Mean Average

1.52 Less Evident

Legend
$3.46-4.00$
Highly Evident
$2.46-3.45$
Evident
$1.36-2.45$
Less Evident
$1.00-1.37$
Least Evident

\subsubsection{Mental Health-Related to Restricted Social Connection}

Table 6 reveals the data on the learner's mental health on Restricted social connection. The over Mean of 1.23 , which's interpreted as "least evident" suggests that the learners were positive that this health crisis is not a lifetime. DepEd has released a memorandum pertaining to health protocol to be safe from COVID19. To cut back the spread of COVsID-19, most governments have opted to employ quarantine protocols and temporarily shut down their academic institutions. As a consequence, more than a billion learners had been affected worldwide. Among this number are over 28 million Filipino learners across academic levels who've to stay at home and observe the Philippine government's quarantine measures (UNESCO, 2020).

Table 6. Learners' Mental Health on Restricted Social Connection

\begin{tabular}{|c|c|c|}
\hline Tndicators & Mean & Interpretation \\
\hline 1.Misses his/her classmates and teachers. & 1.04 & Least Evident \\
\hline 2. Communicates with friends. & 1.03 & Least Evident \\
\hline 3. Allows to go out with friends. & 1.83 & Less Evident \\
\hline 4. Visits his/her friends at home. & 1.82 & Less Evident \\
\hline $\begin{array}{l}\text { 5. Have time for fun and conversation } \\
\text { face to face with his/her classmates. }\end{array}$ & 1.26 & Least Evident \\
\hline $\begin{array}{l}\text { 6. Seek out and support each other } \\
\text { as families, friends and communities. }\end{array}$ & 1.13 & Least Evident \\
\hline 7. Stay connected with peers. & 1.03 & Least Evident \\
\hline $\begin{array}{l}\text { 8. Not losing communication with } \\
\text { Classmates. }\end{array}$ & 1.06 & Least Evident \\
\hline $\begin{array}{l}\text { 9. Emphasizing the safety protocols } \\
\text { when with friends. }\end{array}$ & 1.06 & Least Evident \\
\hline 10.Limit the time of strolling out. & 1.08 & Least Evident \\
\hline
\end{tabular}




\begin{tabular}{lcc}
\hline Mean Average & 1.23 & Least Evident \\
\hline
\end{tabular}

Legend
$3.46-4.00$
Highly Evident
$2.46-3.45$
Evident
$1.36-2.45$
Less Evident
$1.00-1.37$
Least Evident

\subsection{Correlation Between Parent's Interventions and Learner's Mental Health-Related}

Table 7 reveals the correlation results between the Parents' Interventions and Mental Health. The table further shows that the Parents' Interventions' have no significant relationship to Mental Health with a correlational coefficient of .931 and .931 respectively with a significant probability of .000 and .000 . With these results, the null hypothesis was rejected. This means that there is a significant relationship between the parent's intervention and the learner's mental health. It implies that Parental interventions regarding mental health needs and counseling play an important role in their children's mental health as it prevents their children's mental health with symptoms such as anxiety, depression, school closings, and a reduction in social connection. While children are currently unable to study in classrooms, Brossard, Mathieu; Cardoso, Manuel; Kamei, Akito; Mishra, Sakshi; Mizunoya, Suguru; Reuge, Nicolas (2020) opined the importance of learning at home is amplified, and they asserted also that the task of supporting children's learning has fallen to parents at a much larger rate. Dalton, $L$ et al. (2020) recommended psychiatrists and psychologists to study the psychosocial and psychological consequences of the pandemic in the coming months. There is an increase in mental health problems, behavioral disorders, and substance use disorders as extreme stressors can aggravate or cause psychiatric problems.

Table 7. Correlation between Parents' Interventions' and Learners Mental Health

\begin{tabular}{ccc}
\hline Parents' Interventions' & Learner's Mental Health & Interpretation \\
\hline Psychological Needs & $.931^{* *}$ & Highly Significant \\
& .000 & \\
Guidance and Counselling & $.931^{* *}$ & Highly Significant \\
& .000 & \\
${ }^{* *}$ Correlation is significant at the 0.01 level (2-tailed) &
\end{tabular}

\section{CONCLUSION}

Parental "interventions" that include psychological needs and counseling play an important role in the mental health of students with symptoms of anxiety, depression, school closings, and reduced social connection. Parents observed that their children were really affected by the pandemic. They were almost in despair when the education department declared homeschooling with modular learning. With the situation, parents lead their children appropriately not only academically but also psychologically. Guide your children to read their modules and guide them to complete the assigned task. Parents oriented their children to real situations in times of crisis and to the new normal education.

\section{RECOMMENDATION}

Based on the findings of the study, the following recommendations are strongly forwarded:

1. The Department of Education should conduct profiling on the educational and social background of the parents or guardians of the learners that would serve as their basis in coming up programs and activities that will enhance the parents-learners mentoring.

2. There should be close monitoring of teachers' assessment strategies used for enhancing the learner's performance. Regular follow up of assessment result and learning performance is a must.

3. Teachers-parents collaboration on learners' performance should be strengthened to determine the 
strength and weaknesses of the learners and it will serve as bases for further enhancement of learning materials.

4. Schools must use other learning modalities to give consideration to other needs of learners.

5. Further study on the learning development amidst COVID 19 Pandemic.

\section{ACKNOWLEDGEMENT}

This paper would not have been possible without the support of the school heads and educational supervisors of elementary schools of the Maguindanao 1 schools division of Bangsamoro Autonomous Region in Muslim Mindanao and Sultan Kudarat Schools Division of Region XII. The open-handedness and expertise of the referees of this study for their comments and suggestions for the betterment of the paper.

\section{REFERENCE LIST}

Benjamin, L. (1993). Parents' Literacy and Their Children's Success in School: Recent Research, Promising Practices, and Research Implications. Education Research Report.

Brossard, Mathieu; Cardoso, Manuel; Kamei, Akito; Mishra, Sakshi; Mizunoya, Suguru; Reuge, Nicolas (2020). Parental Engagement in Children's Learning: Insights for remote learning response during COVID-19, Innocenti Research Briefs no. 2020-09, UNICEF Office of Research - Innocenti, Florence

Brooks, S. K., Webster, R. K., Smith, L. E., Woodland, L., Wessely, S., Greenberg, N., et al. (2020). The psychological impact of quarantine and how to reduce it: rapid review of the evidence. Lancet 395, 912-920. doi: 10.1016/S0140- 6736(20)30460-8

Ceka, A., \& Murati, R. (2016). The Role of Parents in the Education of Children. Journal of Education and Practice, 7(5), 61-64.

Dalton, L., Rapa, E., and Stein, A. (2020). Protecting the psychological health of children through effective communication about COVID- 19. Lancet Child Adolesc. Health 4:346-347.doi: 10.1016/S23524642(20)30097-3

Emerson, L., Fear, J., Fox, S., \& Sanders, E. (2012). Parental engagement in learning and schooling: Lessons from research. A report by the Australian Research

Wang, C., Pan, R., Wan, X., Tan, Y., Xu, L., Ho, C. S., Ho, R. C. $\quad$ (2020). Immediate psychological responses and associated factors during the initial stage of the 2019 coronavirus disease (COVID19) epidemic among the general population in China. International Journal of Environmental Research and Public Health, 17(5), Article 1729. https://doi.org/10.3390/ijerph17051729

Wang, G., Zhang, Y., Zhao, J., Zhang, J., and Jiang, F. (2020). Mitigate the effects of home confinement on children during the COVID-19 outbreak. Lancet 395, 945-947. doi: 10.1016/S01406736(20)30547-X

WHO (2020). WHO Director-General's opening remarks at the Mission briefing on COVID-19. Retrieved from: https://www.who.int/dg/speeches/detail/who-director- general-s-statement-on-ihr-emergencycommittee-on-novel-coronavirus-(2019)-ncov 